\title{
CANT1 Gene
}

National Cancer Institute

\section{Source}

National Cancer Institute. CANT1 Gene. NCI Thesaurus. Code C97375.

This gene plays a role in both nucleotide hydrolysis and signal transduction. 